\title{
A Community of Interest
}

\author{
Robert F. Welborn \\ Franktown, Colorado
}

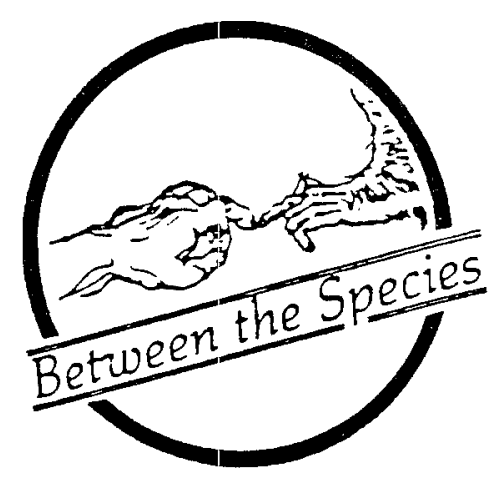

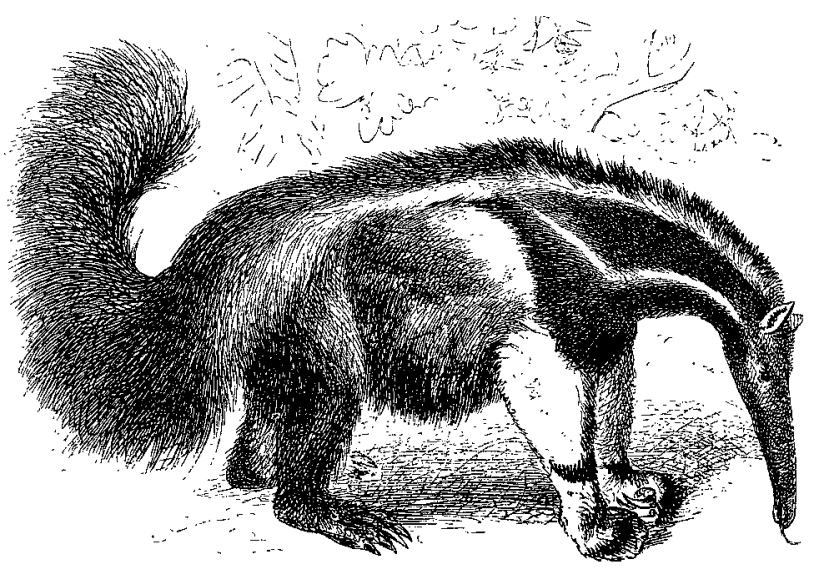

If the human species is to save the life and beauty of this planet from the ravages of its own domination and degradation, we must recognize, develop and act upon a community of interests and aspirations founded upon a respect for all life and for the substances and processes of Nature. We must know that there is a very basic interrelationship among all things in this Earth community and that we humans are responsible, at this desperate hour particularly, morally and practically for the whole. The arts, the sciences, ecology, agriculture, conservation, animal protection, religion, education, all human endeavors have the urgent need and, if we will only realize it, the great opportunity and impetus to aspire together and to work together in a common dedication and in a common goal.

With this community of interest we are inspired and motivated by the realization that the word community in this context of planetary salvation encompasses all life forms, all that is, animate and inanimate, not just human beings, within the area of contemplation, be it small or be it the whole world. Then we realize that without this world community, without Nature, human life and aspirations will stultify and become sterile and decadent. Without Nature and the community of life and evolution the arts and the sciences become meaningless or atrophied. Hunan creations of music, of a Bach suite for cello, human creations of scientific thought, of a concept of universal evolution, are of inspiration and meaning because of the human mind and heart and if that mind and heart are deteriorated, as they will be with world community deterioration, the inspiration and meaning are gone. Being involved in this broadening vista of sustaining and enhancing the Earth community, the living things that make it rich and fruitful, the musician feels and knows that the desecration of the fields and streams is an affront to the music of Bach which it is said sprang from the balance, symmetry and proportion of Nature; the ecologist feels and knows that the massive unnatural suffering of animals in laboratories and factory farms is an affront to the world of living things in the forests and in the oceans that must be viable if life itself is to be viable; the farmer and the consumer of farm produce, indeed all of us, feel and know that the massive infliction of chemicals upon the soil and the plants and the insects is an affront to the very foundation of life itself, the land which Nature through evolution has caused to be so fruitful and beautiful.

When all elements of life are community, then the sensitivities and intelligences which bring people to a concern for the environment are the sensitivities and intelligences which bring people to a concern for animal

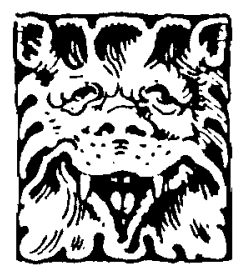


welfare. The environınentalist wants Nature to be respected, wants human usage of the environment to be such that basic natural conditions and aspects are protected and preserved. The person concerned with animal protection wants animals to be treated in ways that recognize them to be sentient beings desirous of life and capable of experiencing pain and misery. The animal welfare person knows that with a deterioration of the environment and a state of human mind that accepts it animals will be more and more brutalized and mechanized, and the environmentalist knows that with animals treated insensitively and unnaturally a callous indifference to environmental degradation will obtain. Such a compelling concern for life and beauty, for plants and animals, for meadows and cows, is the one rational basis for world salvation in quality.

Within all this is the human sense of decency and compassion and the feeling of all living things for life itself, the feeling of Wordsworth:

'Tis my faith that every flower

Enjoys the air it breathes-

This sense and this feeling cringe when a field is desecrated, a tree torn down, a stream polluted and they cringe when a calf is placed in a box to be immobilized and fed anemically so its flesh will be tender or a product to be tested is placed in the eye of a rabbit to see how long it takes to damage the eye. For this sense and feeling what happens to one oak, what happens to one dog is important. Only a concern for the least of this world's creation will carry forward to an effective concern for all of creation.

There is no longer time for human endeavors to develop and operate in isolation. There is no longer time for a person to be just a farmer, just a musician, just a conservationist, just a humanitarian, just a lawyer, just an educator. If these interests and disciplines proceed in isolation, the societies in which they work will deteriorate in isolation. Isolation of the human species within itself and from communion with the world community of living things has brought this world, its life and beauty, to the brink of extinction. Humans isolate themselves by their own anthropocentrism, the assumption that only human life is inportant, that all other life can be used and abused as it can be made to serve present physical needs and comforts of human beings. Nature is to be conquered and made subservient to the manipulations of human science and technology.
Its wisdom is to be ignored. Our hope is in an awakening realization that Nature's substances and processes and living things must be protected and enhanced if human life is to be meaningful and viable.

A few years ago The Christian Science Monitor interviewed prominent people around the world seeking their views as to what should be the primary considerations for the next century. One of the interviewees was Richard von Weizsacker, the president of the then Federal Republic of Germany. The central item on his agenda for the 21st century is the preservation of Nature. He said: "We have been brought up, and our ancestors even more, to understand that nature is serving mankind" but in the future "we will have to realize, in our daily decisions and forms of behavior, that finally we are nothing but a little part in the history of nature. And either we learn to preserve nature-or, if you wish, to preserve creation-or we will not survive." Then came this absolutely profound statement: "We have to preserve nature for nature's own sake, not simply for the sake of mankind."

Nature's sake is the key. If that sake is the community of interest, the common goal of humankind, the preservation and enhancement of the life and beauty of this planet can be achieved. If, however, the interest and the goal are to preserve Nature for humanity's sake, the efforts will be fragmented, often conflicting and in totality unsuccessful. Different peoples, different areas will have different ideas as to what part of Nature is to be saved, what lands are to be preserved, what species are to remain. Saving the environment will be a matter of expediency for the human species and expediency is a vagrant thing, changing from time to time, from place to place, from country to country. While the divergent and special interests are being satisfied, the general deterioration of Nature will continue. Nature's sake recognizes a comprehensive value over and above humankind but encompassing humankind. Spiritually, morally and practically it is the one concept and the one precept that can unify humanity to prevail over its own devolutionary forces. If properly conceived and honored, its foundation will be a general respect, indeed reverence, for all of creation and it will be served with compassion, reason and vitality.

Footnote: Recognition of a community of interest was exemplified in June of this year when senior religious leaders met with prominent scientists and United States Senators under the sponsorship of The 
Joint Appeal in Religion and Science and called for swift action to protect Earth's environment. The emphasis was joint responsibility for the "stewardship of Creation." Another exemplification is in the newly formed Center for Respect of Life and Environment, a division of The Humane Society of the United States. The purpose of the Center is "to promote coordination and unification of the efforts of those who are concerned about the life and beauty of planet Earth." Among its goals is "the coming together of the animal-protection movement with those addressing global environmental issues." On its board of directors is Thomas Berry, whose book, The Dream of the Earth, in the Sierra Club
Nature and Natural Philosophy Library, profoundly tells of the Earth Community. Other board members in addition to persons from the Humane Society are: Andrew Kimbrell, a Washington attorney well known for his action in environmental matters, Fred Kirschenmann, a farmer active in organic and sustainable agriculture who has Ph.D.'s in political science and theology, Dr. Elizabeth Lawrence of Tufts University with interests ranging from veterinary care of animals to anthropology, and Dr. Jay B. McDaniel, a professor of religion and author whose books bring together animals and the environment in a theology of reverence for life, an ecological spirituality.

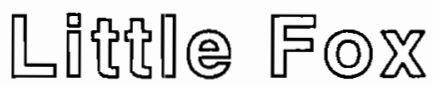

Little fox,

Whelped in a shrinking wild.

Ravenous cub, tearing at meat

Brought to the den

By older, wiser kin.

Playtime,

Measured in months,

Before you face

The strife, the dangers,

And the grim reality of life.

At nature's best, the warming sun,

Rustling leaves, fern-sprinkled ground,

The vagrant and diverting sounds,

A thousand scents to tantalize

A young and curious snout.

Assuaging hunger pangs,

Small prey to seize,

So plentiful in spring

And easy victims to your quick, sharp fangs.

At worst, the cold, harsh winds

Of winter.

Rains and snow
Combine with countless pitfalls

Even for the wary ones.

Somehow you survive

In your lonely way,

Sprinting over fields,

Running just to stay alive,

Foraging for your pound of sustenance a day,

Trying to outpace the hammering hooves,

Eluding baying dogs

Who, following your scent,

Are exhorted on by men

Bent on a senseless kind of sport.

Then, rest and safety in your lair

Until a hunger sends you forth once more.

It happens.

One swift step, a snap,

A leg is pinned.

The trap is closed.

And now

The predators who want your skin,

Violating all the rules of nature,

Win,

Little fox.

Betty Clayton 